\title{
Dampak Kaawasan dan Status Negara Terhadap Pertumbuhan Ekonomi Negara-Negara Terdampak Covid-19
}

\author{
Dedi Junaedi \\ IAI Nasional Laa Roiba Bogor \\ dedijunaedi@laaroiba.ac.id \\ Faisal Salistia \\ IAI Nasional Laa Roiba Bogor \\ faisalsalistia@laaroiba.ac.id
}

\begin{abstract}
The COVID-19 pandemic has had multi-sectoral impacts, including disrupting the economic growth of many countries. This study aims to analyze the impact of the COVID-19 pandemic, fiscal capability as well as regional differences and country status on the economic growth of the affected countries. The method used is a quantitative method with a saturated sample of 135 countries, and a regression analysis approach with dummy variables. The results showed that the variables of pandemic cases, exposure time, population, regional differences and country status differences affected the economic growth of the affected countries (R2 0.6373). If the pandemic is under control and there is no disparity in management between regions and between countries, then global economic growth has the potential to be positive at $0.18 \%$. If state spending is increased, it has the potential to reduce the impact of economic contraction by $0.27 \%$. The management of the pandemic in the Asian, American and African regions is significantly different from that in the Australian region. Poor countries are different from developed countries, but not different from middleincome countries, in managing pandemics in their regions. In relative terms, the impact of the pandemic in Asia, America and Africa is heavier than other regions.
\end{abstract}

Keywords: Impact of Covid-19, Economic Growth, Affected Countries

\begin{abstract}
ABSTRAKS
Pandemi COVID-19 telah menimbulkan dampak multisektor, termasuk mengganggu pertumbuhan ekonomi banyak negara. Penelitian ini bertujuan menganalisis dampak pandemi COVID-19, kemampuan fiskal, serta perbedaan kawasan dan status negara terhadap pertumbuhan ekonomi negara-negara terdampak. Metode yang digunakan adalah metode kuantitatif dengan sampel jenuh 135 negara, dan pendekatan analisis regresi dengan dummy variable. Hasil penelitian menunjukan, variabel kasus pandemi, waktu paparan, jumlah penduduk, perbedaan kawasan dan perbedaan status negara mempengaruhi pertumbuhan ekonomi negara terdampak $\left(R^{2}\right.$ 0.6373). Jika pandemi terkendali serta tidak ada disparitas tatakelola antara kawasan dan antar status negara, maka pertumbuhan ekonomi global berpotensi positif $0.18 \%$. Jika belanja negara dinaikkan, berpotensi menurunkan dampak kontraksi perekonomian sebesar 0.27\% Tatakelola pandemi di kawasan Asia, Amerika dan Afrika berbeda signifikans dengan tatakelola di kawasan Australia. Negara miskin berbeda dengan negara maju, tapi tidak berbeda dengan negara menengah, dalam menata kelola pandemi di wilayahnya. Secara relatif, dampak pandemi di kawasan Asia, Amerika dan Afrika lebih berat dibanding kawasan lainnya. Kata Kunci: Dampak Covid-19, Pertumbuhan Ekonomi, Negara Terdampak
\end{abstract}

\section{PENDAHULUAN}

\subsection{Latar Belakang}

Coronavirus Disease 2019 (COVID-19) telah menjadi pandemi yang menerikan. Wabah global coronavirus ini dalam waktu singkat (dalam hitungan bulan) telah menjalar ke ratusan negara lintas benua. Akhir April 2020, sedikitnya ada 3,5 juta manusia dari 210 negara masuk rumas sakit atau dikarantina mendir. Wabah ini juga telah menyebabkan lebih 250 ribu warga meninggal di rumah-rumah 


\section{Al-Kharaj: Jurnal Ekonomi, Kenangan \& Bisnis Syariah}

Volume 3 No 1 (2021) 37-56 P-ISSN 2656-2871 E-ISSN 2656-4351

DOI: $10.47467 /$ alkharaj.v3i1.187

sakit di kawasan Asia, Amerika, Eropa, Australia, Afrika dan Antartika. Kini (per 30 Agustus 2020) pandemi COVID-19 telah mencapai hampir 25 juta kasus dan 850 ribu lebih kematian di 213 negara dan dua kawasan. Sepanjang Juli-Agustus, setiap hari rata-rata bertambah sekitar 250 ribu kasus dan 6.000 kematian (Worldometer, Agustus 2020).

COVID-19 mula-mula mewabah di Wuhan, Cina, menjelang akhir Desember 2019. Kemudian menjalar ke semua provinsi di sana. Dalam waktu kurang dari dua bulan, coronavirus inti teah menimbulkan 80 ribu kasus dan 3.000 kematian. Mula pekan ketiga Januari 2020,. Covid kemudian menyebrang ke sejumlah negara di Asia, Amerika, Eropa, Autralia dan Arika. Tatkala wabah ini mereda di Cina, penularan COVID-19 justru meledak di sejumlah negara Amerika, Eropa dan Asia. Per 24 April 2020, jumlah kasus tertular di AS, Spanyol, Italia, Perancis, Jerman, Inggris, Turki dan Iran telah melampaui Cina sebagai episentrum awal. Sementara dalam jumlah kematian, ada enam negara yang melebihi Cina, yaitu: AS, Italia, Spanyol, Perancis, Inggris, Jerman, Iran dan Belgia. Sementara jumlah korban di Belanda juga mulai mendekati Cina.

Wabah COVID-19 di Cina memang telah mereda. Kondisi serupa juga dialami sejumlah negara Eropa --yang pada periode Maret-Mei 2020 menjadi episentrum COVID-19-- seperti Italia, Spanyol, Prancis, Ingris, dan Jerman. Episentrum telah bergeser dari Cina ke Eropa, dan kini melanda negara-negata di Amerika Selatan, Amerika Utara, Asia (Timur Tenga) dan Afrika.

Per 30 Agustus, posisi Cina ada di peringkat ke-35 dalam jumlah kasus dan peringkat ke-28 dalam jumlah kematian. Ada 72 negara dengan catatan lebih dari 20.000 kasus dan 1.000 lebih kematian. Kini, Cina ada di posisi ke-35 (85.004 kasus), Indonesia posisi ke-23 (162,884 kasus). Masuk top ten adalah AS, Brazil, India, Rusia, Peru, Afrika Selatan, Colombia, Mexico, Spain, Chile. Di luar itu, negara-negara yang sudah mengalahkan Cina dalam kasus dan kematian berikutnya adalah: Argentina, Iran,Inggris, Saudi Arabia, Bangladesh, Pakistan, Turkey, Italia, Francis, Jerman, Iraq, Filipina, Indonesia, Canada, Qatar, Bolivia, Ukraina, Ekuador, Israel, Kazakhstan, Mesir, Dominika, Panama, dan Oman.

Secara fisik dan psikis, pandemic COVID-19 telah mengganggu dari lebih 8,9 milyar manusia di Asia, Amerika, Eropa, Australia, Afrika dan Antartika khawatir. Sebagian mereka terpaksa harus menjalani fase social distancing (menjaga jarak aman, diam di rumah, bekerja di rumah, bahkan beribadah di rumah) selama berbulan-bulanSatu kondisi yang terbilang mengerikan dari sisi jumlah dan cakupan wilayah wabah.

Pandemi juga telah berdampak luar biasa bagi perekononiam dunia dan negara-negara terdampak. Ancaman resesi bahkan depresi sudah di depan mata. Hatta negara sekuat Singapura, Korea Selatan, Jepang, AS, Selandia Baru, Inggris, Perancis pun sudah merasakannya. Imbasnya juga dialami Indonesia. Dalam dua kuartal berturut-turut pertumbuhan ekonomi nasonal mengalami kontraksi hingga $5,32 \%$.

Untuk mencegah, atau setidaknya menekan, laju penularan sejumlah negara utama terdampak telah melakukan upaya lockdown, karantina wilayah, hingga pembatasan sosial skala besar. (PSBB). Sejumlah penerbangan dihentikan pada banyak negara. Tranportasi darat dan laut juga dibatasi. Sejumlah industry berhenti berproduksi. Pergarakan manusia juga dicegah antar negara, antar provisi, antar wilayah kabupaten dan kota terdampak. Kondisi ini membuat aktivitas ekonomi ikut terdampak. 


\section{Al-Kharaj: Jurnal Ekonomi, Kenangan \& Bisnis Syariah}

Volume 3 No 1 (2021) 37-56 P-ISSN 2656-2871 E-ISSN 2656-4351

DOI: $10.47467 /$ alkharaj.v3i1.187

Soal dampak pandemi terhadap perekonomian telah disampaikan oleh sejumlah peneliti lain sebelumnya. Pandemi Covid-19 dilaporkan berdampak bagi perekonomian Indonesia (Nasution et al (2020) serta Hadiwardojo dan Bhaskara (2020)), perekonomian Arab Saudi (Sikki, 2020), pasar modal Indonesia (Junaedi dan Faisal, 2020), perekonomian regional NTB (Maryanti dan Netrawati, 2020), pasar keuangan global (Zhang et al, 2020), ekonomi global (Smith et al, 2009) dan makroekonomi global (2006).

\subsection{Rumusan Permasalahan}

IMF dan Bank dunia telah memprediksi pandemi COVID-19 dapat memicu resesi ekonomi global. Sejumlah kalangan pakar memperkirakan dampaknya setara atau lebih buruk dari kondisi great depression pada periode 1920-1930. BI dan Menteri Keuangan RI ikut berpandangan bahwa masa depan ekonomi Indonesia juga suram. Setidaknya sampai awal tahun 2021. Pertumbuhan ekonomi tertekan sampai minus -6,13\% pada Agustus 2020 (Sri Mulyani, 2020).

Seberapa besar pandemic berdampak bagi pertumbuhan ekonomi negaranegara di dunia selama? Aspek pandemi apa saja yang mempengaruhi perekonomian global? Apakah perbedaan wilayah ikut mempengaruhi besaran dampak pandemic terhadap perekonomian? Untuk menjawabnya dilakukan penelitian berjudul: Dampak Pandemi COVID-19 terhadap Pertumbuhan Ekonomi Negara-negara Terdampak. Waktu penelitian ini dilakukan dalam periode Januari - September 2020.

\subsection{Tujuan Penelitian}

1. Mengeksplorasi dampak pandemi Covid dan kemampuan fiskal terhadap pertumbuhan ekonomi negara-negara terdampak.

2. Menganalisis pengaruh perbedaan kawasan dan status negara terhadap tingkat pertumbuhan ekonomi negara-negara dalam masa pandemic COVID19.

\section{KERANGKA TEORITIS DAN PENGEMBANGAN HIPOTESIS}

\subsection{PDB dan Perekonomian Global}

Produk Domestik Bruto atau GDP (Gross Domestic Product), menurut Mankiw (2006:5) adalah statistik perekonomian penting karena dianggap sebagai indikator terbaik mengenai kesejahteraan masyarakat. McEachern (2000:146) berpendapat, PDB adalah jumlah nilai pasar dari barang dan jasa akhir yang diproduksi oleh sumber daya suatu negara selama jangka waktu tertentu, biasanya satu tahun. PDB juga dapat digunakan untuk mempelajari perekonomian dari waktu ke waktu. PDB ditentukan berdasarkan dua pendekatan: pendekatan pengeluaran, (menjumlahkan seluruh pengeluaran agregat pada seluruh barang dan jasa akhir yang diproduksi selama satu tahun); Pendekatan pendapatan (menjumlahkan seluruh pendapatan agregat yang diterima selama satu tahun oleh mereka yang memproduksi output tersebut).

PDB dapat dihitung dengan dua pendekatan, yaitu pendekatan pengeluaran dan pendekatan pendapatan (Callen, 2016). Rumus umum PDB dengan pendekatan pengeluaran adalah: $\mathrm{PDB}=$ konsumsi + investasi + pengeluaran pemerintah $+($ ekspor - impor). Di mana konsumsi adalah pengeluaran yang dilakukan oleh rumah tangga, 


\section{Al-Kharaj: Inrual Ekonomi, Kenangan \& Bisnis Syariah}

Volume 3 No 1 (2021) 37-56 P-ISSN 2656-2871 E-ISSN 2656-4351

DOI: $10.47467 /$ alkharaj.v3i1.187

investasi oleh sector usaha, pengeluaran pemerintah oleh pemerintah, dan ekspor dan impor.

Sementara pendekatan pendapatan menghitung pendapatan yang diterima faktor produksi: $\mathrm{PDB}=$ sewa + upah + bunga + laba. Di mana sewa adalah pendapatan pemilik faktor produksi tetap seperti tanah, upah untuk tenaga kerja, bunga untuk pemilik modal, dan laba untuk pengusaha. Secara teori, menurut Lequiller (2006), PDB dengan pendekatan pengeluaran dan pendapatan harus menghasilkan angka yang sama. Namun, karena dalam praktik menghitung PDB dengan pendekatan pendapatan sulit dilakukan, maka yang sering digunakan adalah dengan pendekatan pengeluaran.

\subsection{Pertumbuah Ekonomi}

Pertumbuhan ekonomi merupakan faktor penting dalam mengurangi kemiskinan dan menghasilkan sumber daya yang diperlukan bagi pembangunan manusia dan perlindungan lingkungan. Perekonomian mengalami ekpansi jika ada pertumbuhan positif. Sebaliknya, perekonomian mengalami kontraksi jika pertumbuhannya negatif. Namun, pertumbuhan ekonomi saja tidak menjamin pembangunan manusia. Selain pertumbuhan ekonomi yang tercermin dalam statistik PDB dan pendapatan per kapita, diperlukan adanya jaminan keamanan, tersedianya akses pendidikan dan layanan kesehatan dan pendidikan. Maka, berkembanglah konsep indeks pembangunan manusia (IPM).

Di luar PDB, beberapa konsep muncul seperti indeks pembangunan manusia (IPM), indeks kesejahteraan rakyat (ikrar) dan indeks kesejahteran ekonomi (Eurostat). Jauh sebelumnya, Islam sejatinya sudah memperkenalkan konsep indeks maslahat sebagai esensi utama dari maqosid syariah atau tujuan diberkalukannya syariah Islam (Junaedi, 2020).

Menurut Robert J. Gordon (2016, pertumbuhan Global Gross Domestic Product (GDP) suatu negara dipengaruhi oleh berbagai faktor. Antara lain faktor akumulasi modal, produktivitas sumberdaya alam, sumberdaya manusia, kelembagaan politik, kewirausahaan dan produk baru, perubahan struktur perekonomian, dan faktor lingkungan (wabah penyakit, bernacna alam, perubahaan iklim akibat pemanasan global), serta keterbatasan sumnerdaya dan energi.

\subsection{Pandemi COVID-19 Global}

Wabah COVID-19 bermulai dari Wuhan, Cina. Pada 31 Desember 2019, WHO China Country Office melaporkan kasus pneumonia yang tidak diketahui etiologinya di Kota Wuhan, Provinsi Hubei, Cina. Pada tanggal 7 Januari 2020, Cina mengidentifikasi pneumonia yang tidak diketahui etiologinya tersebut sebagai jenis baru coronavirus (coronavirus disease, COVID-19). Pada tanggal 30 Januari 2020 WHO telah menetapkan sebagai Kedaruratan Kesehatan Masyarakat Yang Meresahkan Dunia/ Public Health Emergency of International Concern (KKMMD/PHEIC). Penambahan jumlah kasus COVID-19 berlangsung cukup cepat dan sudah terjadi penyebaran antar negara (Neufeld, 2020).

Sampai dengan tanggal 30 Agustus 2020, dilaporkan total kasus konfirmasi mencapai 25 juta lebih dengan jumlah lebih 850,6 ribu lebih kematian Ada 213 negara dan dua kawasan teritori yang terdampak pandemic Covis-19. Hampir separuhnya dilaporkan memiliki lebih dari 50 ribu kasus dengan lebih dari 1.000 kematian. Setiap hari selama Juli - Agustus 2020, rata-rata ada tambahan 250 ribu kasus dan 6.000 kematian (Worldometer, 30 Agustus 2020). 


\section{Al-Kharaj: Jurnal Ekonomi, Kenangan \& Bisnis Syariah}

Volume 3 No 1 (2021) 37-56 P-ISSN 2656-2871 E-ISSN 2656-4351

DOI: $10.47467 /$ alkharaj.v3i1.187

Bila dalam Triwulan I , Cina menjadi episentrum utama pandemic Covis-19, kini ada 35 negara terdampak yang sudah melampaui Cina dalam catatan kasus dan kematian akibat Covid.-19. Dalam delapan bulan masa pandemic, episentrum pandemic telah bergeser dari Cina ke Eropa, dan kini melanda negara-negata di kawasan Amerika Selatan, Amerika Utara, Asia (Timur Tengah) dan Afrika.

Banyak pihak, pakar perorangan maupun lembaga kredibel, mengkhawatirkan pandemic tak hanya berdampak krisis eknomi tapi juga depresi ekonomi dengan besaran dampak lebih kuatndan besar dan lebih lama dibanding krisis 1997-1998. Pandemi juga telah berdampak luar biasa bagi perekononiam dunia dan negara-negara terdampak. Ancaman resesi bahkan depresi sudah dan sedang menimpa banyak negara terdampak. Hatta negara sekuat Singapura, Jepang, Korena, Korea Selatan, AS pun sudah merasakannya. Pasar modal juga ikut bergolak. (Junaedi, 2020)

\section{Distribusi Kasus Pandemi CoVID-19}

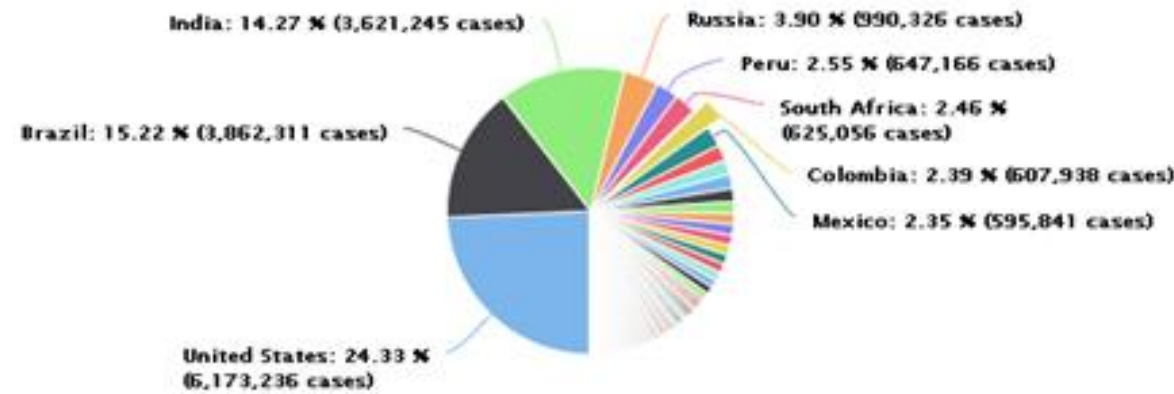

Grafik 1 Distribusi Akumulasi Kasus Pandemi COVID-19

Sumber: Worldometer.info 31 Agustus 2020

Dana Moneter Internasional (IMF) memproyeksi kerugian perekonomian global akibat pandemi virus corona bisa mencapai 12 triliun dollar AS atau sekitar Rp 174.000 triliun (kurs Rp 14.500). Direktur Pelaksana IMF Kristalina Georgieva menjelaskan, pandemi telah membawa perekonomian global jatuh ke dalam jurang krisis. Sebab, 95 persen negara-negara di dunia diproyeksi bakal mengalami kontraksi atau atau pertumbuhan ekonomi di zona negatif.

Pasar modal dan perekonomian berkembang diproyeksi IMF bakal menghadapi pertumbuhan pendapatan per kapita negatif pada 2020. Pasar dan negara berkembang, kecuali China, diperkirakan bakal mengalami pukulan lebih besar dalam pertumbuhan Produk Domestik Bruto (PDB) ketimbang negara maju pada tahun 2020 hingga 2021, (Georgieva, 2020). IPertumbuhan ekonomi dunia diprediksi mengalami kontraksi atau tumbuh negatif 4,9 persen tahun 2020 ini. Angka tersebut lebih tinggi 1,9 poin dari proyeksi sebelum April 2020 (-3.0\%. Secara berturut-turut, IMF memproyeksi pertumbuhan ekonomi kelompok negara maju sebagai berikut; Amerika Serikat -8 persen, Jepang -5,8 persen, Inggris $-10,2$ persen, Jerman - 7,8 persen, Prancis, -12,5 persen, sementara Italia dan Spanyol tumbuh -12,8 persen. Untuk Indonesia , IMF memproyeksi bakal mengalami kontraksi atau tumbuh negatif 0,3 persen pada tahun ini. Tapi prediksi ini meleset mengingat faktanya, Indonesia, seperti dsampaikan Presiden Jokowi dan Menkeu Sri Mulyani PDB Indonesia dalam kuartal II sudah menyusut -5,2\%. Bahkan, pada Agustus kontraksi ekonomi Indonesia sudah mencapai -6,13\% (Sri Mulyani, 2020). 


\section{Al-Kharaj: Jurnal Ekonomi, Kenangan \& Bisnis Syariah}

Volume 3 No 1 (2021) 37-56 P-ISSN 2656-2871 E-ISSN 2656-4351

DOI: $10.47467 /$ alkharaj.v3i1.187

\subsection{Dampak Pandemi terhadap Pertumbuhan Ekonomi}

Adanya potensi dampak pandemic COVID-19 terhadap perekonomian global sudah diprakirakan oleh beberapa pihak. Antara lain IMF, Worldbank dan World Efocomy Forum. IMF, misalnya, telah memuat prediksi pada Maret dan Juni 2020. Fiscal Monitoring IMF 2020 antara lain menyampaikan informasi dan prakiraan beberapa indikator fiskal moneter negara-negara terdampak (seperti ditunjukkan dalam Tabel 1). IMF membuat tiga katagori negara; yaitu: Advance Economiies (negara maju), Emerging Market and Middle Income Economes (negara berkembang dan menengah), serta negara Low Income Developing Countries (negara miskin).

Tim ekonomi IMF memprediksi selama pandemi COVID-19 negara-negara maju (Advance Country) mengalami kontraksi pertumbuhan ekonomi antara $-5,5 \%$ (Jerman) hingga $-15,4 \%$ (AS). Selama pandemi, rata-rata negara-negara maju diprediksi mengalami pertumbuhan minus $10.7 \%$.

Tabel 1 Proyeks Pertumbuahn GDP Negara Terdampak COVID-19

Sumber: Monitoring Fiscal IMF, Juni 2020

\begin{tabular}{|c|c|c|c|c|c|c|c|c|c|}
\hline & & & & & & & & & $\begin{array}{l}\text { Projection } \\
\text { s }\end{array}$ \\
\hline & $\begin{array}{l}201 \\
2\end{array}$ & $\begin{array}{l}201 \\
3\end{array}$ & $\begin{array}{l}201 \\
4\end{array}$ & $\begin{array}{l}201 \\
5\end{array}$ & $\begin{array}{l}201 \\
6\end{array}$ & $\begin{array}{l}201 \\
7\end{array}$ & $\begin{array}{l}201 \\
8\end{array}$ & $\begin{array}{l}201 \\
9\end{array}$ & 2020 \\
\hline World & -3.8 & -2.9 & -2.9 & -3.3 & -3.4 & -3.0 & -3.1 & -3.7 & -9.9 \\
\hline Advanced Economies & -5.5 & -3.7 & -3.1 & -2.6 & -2.6 & -2.3 & -2.6 & -3.0 & -10.7 \\
\hline United States 1 & -8.0 & -4.6 & -4.0 & -3.6 & -4.3 & -4.5 & -5.7 & -5.8 & -15.4 \\
\hline Euro Area & -3.7 & -3.0 & -2.5 & -2.0 & -1.4 & -0.9 & -0.5 & -0.7 & -7.5 \\
\hline France & -5.0 & -4.1 & -3.9 & -3.6 & -3.5 & -2.8 & -2.3 & -3.0 & -9.2 \\
\hline Germany & 0 & 0 & 0.6 & 0.9 & 1.2 & 1.2 & 1.9 & 1.4 & -5.5 \\
\hline Italy & -2.9 & -2.9 & -3.0 & -2.6 & -2.4 & -2.4 & -2.2 & -1.6 & -8.3 \\
\hline Spain2 & $\overline{1}-\overline{1}$ & -7.0 & -5.9 & -5.2 & -4.3 & -3.0 & -2.5 & -2.6 & -9.5 \\
\hline Japan & -8.6 & -7.9 & -5.6 & -3.8 & -3.7 & -3.1 & -2.4 & -2.8 & -7.1 \\
\hline United Kingdom & $\begin{array}{ll}-7.6 \\
\end{array}$ & -5.5 & -5.6 & -4.6 & -3.3 & -2.5 & -2.2 & -2.1 & -8.3 \\
\hline Canada & -2.5 & -1.5 & 0.2 & -0.1 & -0.5 & -0.1 & -0.4 & -0.4 & -11.8 \\
\hline Others & 0.4 & 0.2 & 0.2 & 0.1 & 0.7 & 1.4 & 1.4 & 0 & -5.3 \\
\hline $\begin{array}{l}\text { Emerging Market and Middle- } \\
\text { Income Economies }\end{array}$ & -0.9 & -1.5 & -2.5 & -4.4 & -4.8 & -4.1 & -3.8 & -4.8 & -9.1 \\
\hline $\begin{array}{l}\text { Excluding MENAP Oil } \\
\text { Producers }\end{array}$ & -1.9 & -2.3 & -2.7 & -4.0 & -4.4 & -4.0 & -4.0 & -5.0 & -9.0 \\
\hline Asia & -1.6 & -1.8 & -1.9 & -3.3 & -3.9 & -4.0 & -4.5 & -6.0 & -9.9 \\
\hline China & -0.3 & -0.8 & -0.9 & -2.8 & -3.7 & -3.8 & -4.7 & -6.4 & -11.2 \\
\hline India & -7.5 & -7.0 & -7.1 & -7.2 & -7.1 & -6.4 & -6.3 & -7.4 & -7.4 \\
\hline Europe & -0.7 & -1.5 & -1.4 & -2.7 & -2.9 & -1.8 & 0.4 & -0.7 & -6.1 \\
\hline Russia & 0.4 & -1.2 & -1.1 & -3.4 & -3.7 & -1.5 & 2.9 & 1.9 & -4.8 \\
\hline Latin America & -2.9 & -3.2 & -5.0 & -6.8 & -6.2 & -5.4 & -5.2 & -4.0 & -6.7 \\
\hline Brazil & -2.5 & -3.0 & -6.0 & $\overline{-} \overline{10.3}$ & -9.0 & -7.9 & -7.2 & -6.0 & -9.3 \\
\hline Mexico & -3.7 & -3.7 & -4.5 & -4.0 & -2.8 & -1.1 & -2.2 & -2.3 & -4.2 \\
\hline MENAP & 5.6 & 3.9 & -1.5 & -8.5 & -9.6 & -5.8 & -2.9 & -3.8 & -9.8 \\
\hline Saudi Arabia & 11.9 & 5.6 & -3.5 & $\overline{15.8}$ & $\begin{array}{l}- \\
17.2\end{array}$ & -9.2 & -5.9 & -4.5 & -12.6 \\
\hline South Africa & -4.4 & -4.3 & -4.3 & -4.8 & -4.1 & -4.4 & -4.1 & -6.3 & -13.3 \\
\hline $\begin{array}{l}\text { Low-Income Developing } \\
\text { Countries }\end{array}$ & -2.0 & -3.3 & -3.2 & -3.8 & -3.7 & -3.6 & -3.8 & -4.1 & -5.7 \\
\hline Nigeria & 0.2 & -2.3 & -2.1 & -3.2 & -4.0 & -5.4 & -4.3 & -5.0 & -6.4 \\
\hline
\end{tabular}




\section{Al-Kharaj: Inrual Ekonomi, Kenangan \& Bisnis Syariah}

Volume 3 No 1 (2021) 37-56 P-ISSN 2656-2871 E-ISSN 2656-4351

DOI: $10.47467 /$ alkharaj.v3i1.187

\begin{tabular}{|l|l|l|l|l|l|l|l|l|l|} 
Oil Producers & $\mathbf{1 . 6}$ & $\mathbf{0 . 4}$ & $\mathbf{- 1 . 1}$ & $\mathbf{- 4 . 2}$ & $\mathbf{- 4 . 6}$ & $\mathbf{- 2 . 6}$ & $\mathbf{- 0 . 6}$ & $\mathbf{- 1 . 0}$ & $\mathbf{- 7 . 6}$ \\
\hline Memorandum & & & & & & & & & \\
\hline World Output (percent) & 3.5 & 3.5 & 3.6 & 3.5 & 3.4 & 3.9 & 3.6 & 2.9 & -3.0 \\
\hline
\end{tabular}

Negara menengah dan berkembang (Emerging Country and Midle Country) mengalami kontaksi antara -4,8 (Rusia) hingga -13,3\% (Afrika Selatan). Selama pandemi, rata-rata negara menengah mengalami pertumbuhan ekonomi minus $9.1 \%$ Negara miskin (Low Income Developing Contry) diprediksi IMF mengalami kontraksi pertumbuhan ekonomi rata-rata $-5,7 \%$. Sepintas efek kontraksi ekonomi yang dihadapi negara-negara miskin relatif lebih kecil dibanding negara menengah dan negara maju.

\section{METODOLOGI PENELITIAN}

\subsection{Metode Penelitian}

Penelitiaan ini menggunakan metode analisis kuantitatif dengan pendekatan regresi ganda dummy variabel. Teknik pengambilan sampel jenuh dari 135 negara terdampak. Data yang digunakan umumnya merupakan data sekunder yang diperoleh dari IMF, WHO, dan Worldometer, serta sumber-sumber referensi online yang tersebar dalam berbagai portal informasi maupun berita. Sebagian besar data pertumbuhan GDP, penerimaan, belanja negara dan utang negara diambil dari Fiscal Monitor IMF Juni 2020, sementara data pandemic COVID-19 diambil dari situs WHO dan portal coronavirus Worldometer.org.

Data yang terkumpul selanjutnya dikelompokkan menjadi variabel terikat (dependent) dan variabel bebas (independent). Variabel terikat adalah nilai pertumbuhan PDB (G-GDP). Sedang variabel bebas adalah jumlah kasus. Kasus aktif, aksus kritis, waktu mulai terpapar, lamanya waktu terpapar, jumlah kematian, jumlah tes PCR, pengeluaran dan utang negara dari 135 entitas negara. Selain juga ada dua kelompok variabel dummy: perbedaan kawasan (Austrial/Oceania, Afrika, Asia, Eropa, Amerika Utara, Amerika Selatan), sebagai pembanding atau variabel referensnya adalah negara Asutaralia/Oceania. Variabel dummy lainnya dalah perbedaan status negara: negara maju (Advance Country), negara berkembang (Emerging Country), dan negara miskin (Low Income Country/LIC), menruut definisi IMF. Negara miskisn sebagai variabel referensnya.

Variabel dummy dibuat untuk melihat pengaruh perbedaan kawasan dan perbedaan status negara. Untuk katagori kawasan, Australia/Oceania digunakan sebagai sebagai variabel pembanding atau rujukan. Sementara untuk katagori status negara, negara miskin (LIC) menjadi variabel rujukan.

\subsection{Model Ekonometri}

Data olahan dianalisis secara kuantitatif deskriptif dengan model regresi berganda dengan dummy variable. Aplikasi Eviews 10 digunakan untuk menganalisis pengaruh pandemi COVID-19, kemampuan fiskal, serta perbedaan kawasan dan status negara terhadap dinamika pertumbuah PDB (G-GDP). Model ekonometrik yang digunakan sebagai berikut: 


\section{Al-Kharaj: Inrual Ekonomi, Kenangan \& Bisnis Syariah}

Volume 3 No 1 (2021) 37-56 P-ISSN 2656-2871 E-ISSN 2656-4351

DOI: $10.47467 /$ alkharaj.v3i1.187

G-GDP $=\beta_{0}+\beta_{1}$ TCases $+\beta_{2}$ TDeath $+\beta_{3}$ Pop $+\beta_{4}$ G-GDP- $1+\beta_{5}$ T-Morbids $+\beta_{6}$ Expen $+\beta_{7}$ Debt $+\beta_{8}$ Amerika $+\beta_{9}$ Afrika $+\beta_{10}$ Asia $+\beta_{11}$ Eropa $+\beta_{12}$ ADVANCE $+\beta_{13}$ EMERGE + $\varepsilon$

\section{Hipotesis Penelitian}

Hipotesis I

$\mathrm{H}_{10}$ Pandemi COVID-19 dan kemampuan fiskal moneter tidak berpengaruh terhadap pertumbuhan PDB

$\mathrm{H}_{11} \quad$ Pandemi COVID-19 dan kemampuan fiskal moneter berpengaruh terhadap pertumbuhan PDB

Hipotesis 2

$\mathrm{H}_{20} \quad$ Perbedaan kawasan dan status negara tidak berpengaruh terhadap pertumbuhan PDB

$\mathrm{H}_{21} \quad$ Perbedaan kawasan dan status berpengaruh terhadap pertumbuhan PDB

Sebelum dianalisis lebih jauh, dilakukan uji t, uji $\mathrm{F}$ dan uji asumsi klasik (multikolinieritas, heteroskedalitas, autokorelasi, linieritas, dan normalitas).

\section{HASIL DAN PEMBAHASAN}

\subsection{Pandemi COVID-19}

Sampai 30 Agustus 2020, pandemic COVID-19 telah terjadi di 213 negara dari enam kawasan. Yaitu: Amerika Utara, Amerika Selatan, Eropa, Asia, Afrika, dan Oceania. Asia Dari hari ke hari angka kasus dan kematian terus bertambah. Secara akumulatif ada 25.390 .069 kasus, 850.615 kematian, 17.709 .077 orang sembuh, 6.830.377 kasus aktif, dan ada 61.101 kasus seris (kritis). Mereka tersebar di Amerika Utara 28.8\%, Asia (27,56\%), Amerika Selatan (24.59\%), Eropa (14,0\%), Afrika (4,92\%) dan Australia/Oceania (0.11\%)., Tabel rinci angka kasus, kematian, kasus aktif, kasus kritis, total tes dan jumlah populasi dapat dilihat pada Tebel 1.

Tabel 2 Kasus Pandemi COVID-19 per 30 Agustus 2020

Sumber: Worldometer 30 Agustus 2020, diolah

\begin{tabular}{|l|l|l|l|l|l|l|}
\hline Kawasan & Negara & Kasus & Meninggal & Sembuh & Test & Populasi \\
\hline $\begin{array}{l}\text { Amerika } \\
\text { Selatan }\end{array}$ & 14 & 6244321 & 201164 & 4834353 & 26659437 & 431343377 \\
\hline & $6.57 \%$ & $24.59 \%$ & $23.65 \%$ & $27.30 \%$ & $5.80 \%$ & $5.29 \%$ \\
\hline $\begin{array}{l}\text { Amerika } \\
\text { Utara }\end{array}$ & 39 & 7312603 & 270532 & 4203181 & 90877241 & 589866928 \\
\hline & $18.31 \%$ & $28.80 \%$ & $31.80 \%$ & $23.73 \%$ & $19.77 \%$ & $7.23 \%$ \\
\hline Eropa & 48 & 3555640 & 207400 & 2065754 & 115850651 & 747707013 \\
\hline & $22.54 \%$ & $14.00 \%$ & $24.38 \%$ & $11.66 \%$ & $25.20 \%$ & $9.16 \%$ \\
\hline Asia & 49 & 6998654 & 141205 & 5602612 & 188590955 & 4615185050 \\
\hline & $23.00 \%$ & $27.56 \%$ & $16.60 \%$ & $31.64 \%$ & $41.02 \%$ & $56.55 \%$ \\
\hline Afrika & 57 & 1250375 & 29633 & 979996 & 11071333 & 1345627090 \\
\hline & $26.76 \%$ & $4.92 \%$ & $3.48 \%$ & $5.53 \%$ & $2.41 \%$ & $16.49 \%$ \\
\hline Oceania & 6 & 28,476 & 681 & 23,181 & $7,010,852$ & $40,989,145$ \\
\hline & $2.82 \%$ & $0.11 \%$ & $0.08 \%$ & $0.13 \%$ & $1.53 \%$ & $0.50 \%$ \\
\hline
\end{tabular}




\section{Al-Kharaj: Jurnal Ekonomi, Kenangan \& Bisnis Syariah}

Volume 3 No 1 (2021) 37-56 P-ISSN 2656-2871 E-ISSN 2656-4351

DOI: $10.47467 /$ alkharaj.v3i1.187

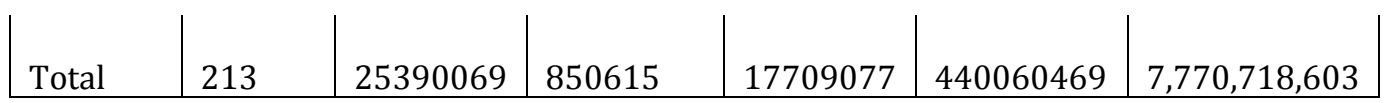

Secara kuantitas, kawasan Amerika Utara dan Asia menjadi kawasan paling banyak terdampak kasus pandemi. Sementara Eropa termasukk kawasan paling banyak melaporkan kematian akibat COVID-19. Amerika Utara yang memiliki penduduk 589,9 jutajiwa mencatatkan 7,313 juta kasus dan 270,5 ribu kematian. Asia dimana ada 4,615 milyar manusia tinggal, memiliki catatan 6,999 juta kasus dan 141 ribu kematian. Berikutnya adalah Amerika Utara (dihuni 431,34 juta memiliki 6,244 juta kasus dan 201 ribu kematian. Urutan berikutnya adalah Eropa, Afrika, dan Oceania. Eropa memiliki 355,56 juta kasus dan 270,532 kematian. Afrika memiliki 1,25 juta kasus dan 29.633 kematian. Sementara Oceania yang dihuni 40,9 juta jiwa baru mencatatkan 28.476 kasus dan 681 kematian akibat COVID-19.

Jika memperhatikan grafik harian, pandemic ini sudah melewati fase dua gelombang. Tambahan kasus dan kematian harian masih terbilang tinggi. Selama bulan Agustus, setiap hari asus bertambah lebih dari 250 ribu, sementara angka kematian rata-rata bertambah sekitar 6.000 per hari. Dalam jumlah kasus, gelombang kedua lebih tinggi dibanding gelombang kedua. Sementara dalam kematian, puncak gelombang kedua tampak lebih rendah dari puncak gelombang pertama. Ada tren puncak gelombang kedua sudah dilalui dan kini memasuki fase puncak menurun,
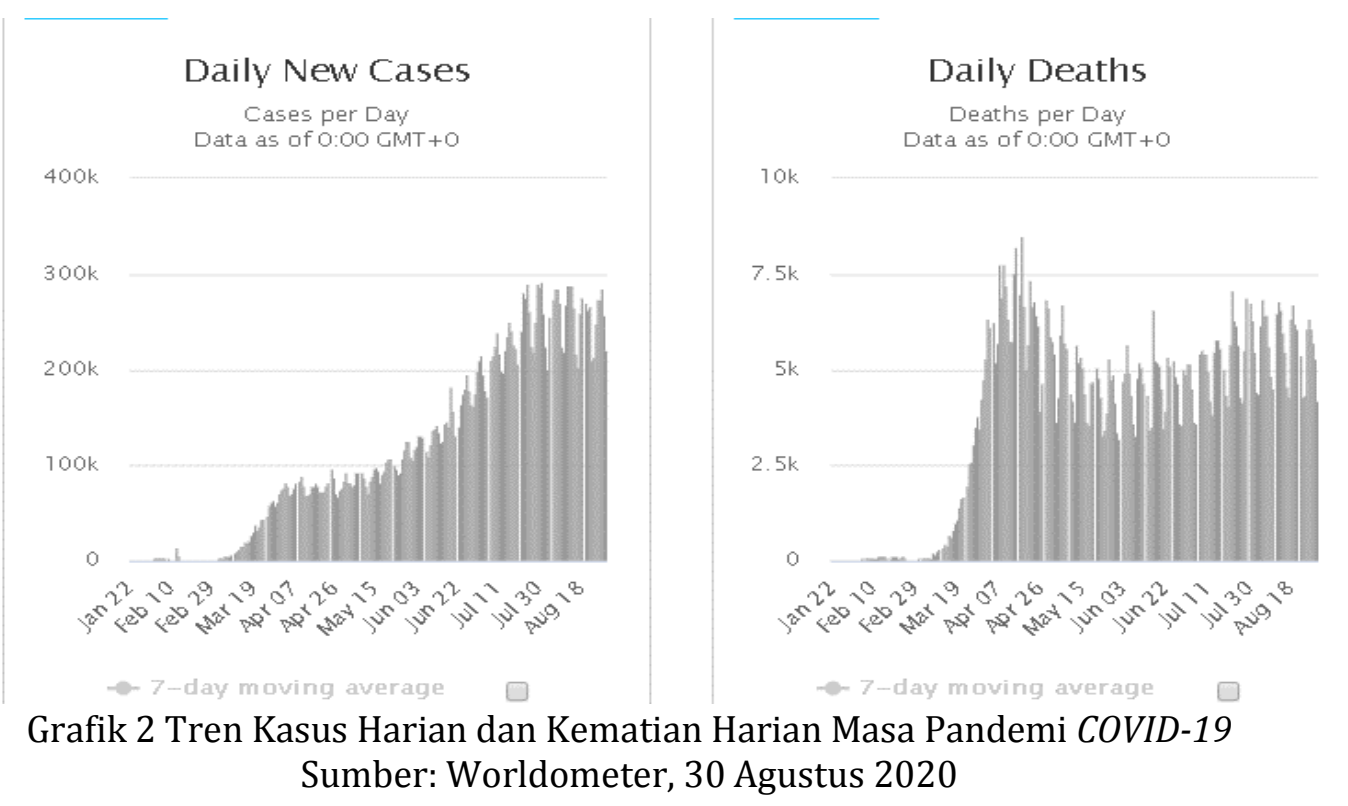

\subsection{Pengaruh Pandemi terhadap Pertumbuhan}

Seberapa besar pandemi berdampak bagi pertumbuhan ekonomi? Monitoring Fiskal IMF Juli 2020 -sebagaimana ditampilkan dalam Tabel 1) menyajikan proyeksi pertumbuhan sejumlah negara terdampak selama masa pandemic. Dampak pandemic Covid terhadap pertumbuhan ekonomi punya variasi yang lebar. IMF membuat tiga katagori negara; yaitu: Advance Economiies (negara maju), Emerging Market and Middle Income Economes (negara berkembang dan menengah), serta negara Low Income Developing Countries (negara miskin).

Tim ekonomi IMF memprediksi selama pandemi COVID-19 negara-negara maju (Advance Country) mengalami kontraksi pertumbuhan ekonomi antara -5,5\% 


\section{Al-Kharaj: Inrual Ekonomi, Kenangan \& Bisnis Syariah}

Volume 3 No 1 (2021) 37-56 P-ISSN 2656-2871 E-ISSN 2656-4351

DOI: $10.47467 /$ alkharaj.v3i1.187

(Jerman) hingga $-15,4 \%$ (AS). Selama pandemi, rata-rata negara-negara maju diprediksi mengalami pertumbuhan minus $10.7 \%$.

Negara menengah dan berkembang (Emerging Country and Midle Country) mengalami kontaksi antara -4,8 (Rusia) hingga -13,3\% (Afrika Selatan). Selama pandemi, rata-rata negara menengah mengalami pertumbuhan ekonomi minus $9.1 \%$ Negara miskin (Low Income Developing Contry) diprediksi IMF mengalami kontraksi pertumbuhan ekonomi rata-rata $-5,7 \%$.

Sepintas efek kontraksi ekonomi yang dihadapi negara-negara miskin relatif lebih kecil dibanding negara menengah dan negara maju. Apakah perbedaan kawasan dan status negara ikut berpengaruh dalam tatakelola negara dalam mengatasi masalah perekonomian selama pandemi? Untuk itu dilakukan analisis statistik regresi berganda dengan dummy variabel mengunakan software aplikasi Eviews 10. Output hasil analisis ditampilkan dalam Tabel 3.

Tabel 3 Hasil Regresi Dampak Pandemi terhahad Pertumbuhan Ekonomi Sumber: Data IMF dan Worldometer diolah EViews 10

Dependent Variable: DG_GDP

Method: Least Squares

Date: 08/31/20 Time: 17:21

Sample (adjusted): 3217

Included observations: 147 after adjustments

\begin{tabular}{crrrr}
\hline \hline Variable & Coefficient & Std. Error & t-Statistic & Prob. \\
\hline \hline DTCASES & $4.15 \mathrm{E}-06$ & $1.84 \mathrm{E}-06$ & 2.252963 & 0.0259 \\
DTEST & $-1.22 \mathrm{E}-07$ & $8.79 \mathrm{E}-08$ & -1.386973 & 0.1678 \\
T_MORBID & -0.303046 & 0.037515 & -8.078086 & 0.0000 \\
GDP-1 & 0.000349 & 0.000490 & -0.711992 & 0.0477 \\
LOGPOP & -3.261571 & 0.868373 & -3.755957 & 0.0003 \\
AFRIKA & -12.92822 & 7.738935 & -1.670542 & 0.0972 \\
AMERICA & -14.40056 & 6.821408 & -2.111083 & 0.0366 \\
ASIA & -15.65950 & 7.085263 & -2.210150 & 0.0288 \\
EUROPE & -10.58930 & 11.87675 & -0.891599 & 0.3742 \\
EMERGE & -4.605343 & 3.326520 & -1.384433 & 0.1685 \\
ADVANCE & -15.53806 & 4.212644 & -3.688434 & 0.0003 \\
EXP01 & -0.279737 & 11.11455 & -2.516825 & 0.0130 \\
DEBT & 3.470767 & 2.986292 & 1.162233 & 0.2472 \\
C & 0.1801173 & 16.85937 & 10.68351 & 0.0000 \\
\hline \hline R-squared & 0.637264 & Mean dependent var & 42.44898 \\
Adjusted R-squared & 0.601809 & S.D. dependent var & 17.97075 \\
S.E. of regression & 11.33997 & Akaike info criterion & 7.784937 \\
Sum squared resid & 17103.13 & Schwarz criterion & 8.069741 \\
Log likelihood & -558.1929 & Hannan-Quinn criter. & 7.900656 \\
F-statistic & 17.97369 & Durbin-Watson stat & 2.027738 \\
Prob(F-statistic) & 0.000000 & & \\
\hline \hline
\end{tabular}

Dari hasil analisis regresi berganda dengan dummy variabel sepintas diperoleh informasi bahwa variabel-variabel bebas secara simultan tampak 


\section{Al-Kharaj: Inrual Ekonomi, Kenangan \& Bisnis Syariah}

Volume 3 No 1 (2021) 37-56 P-ISSN 2656-2871 E-ISSN 2656-4351

DOI: $10.47467 /$ alkharaj.v3i1.187

mepengaruhi perkembangan pertumbuhan GDP dengan tingkat determinasi 63,73\% (ditunjukkan $R$-squared 0.637264). Artinya model regresi dapat menjelaskan sebanyak 63,73\%, sisanya (36,27\%) dipengaruhi oleh variabel lain yang tidak diteliti.

Secara parsial jumlah kasus (DTCases), waktu terpapar pandemi (T-Morbid), GDP-1, jumlah penduduk, kemampuan bekanja, perbedaaan status negara dan perbedaan kawasan mempengaruhi dinamika pertumbuhan GDP. Namun begitu, temuan ini perlu divalidasi terlebih dahulu dengan menujinya melalui seperangkat uji asumsi klasik.

\section{Uji Asumsi Klasik}

Untuk itu perlu dilakukan terlebih dahulu uji asumsi klasik. Antara lain meliputi uji multikolinearitas, uji heteroskedalitas, uji linearitas, uji autokorelasi, dan uji normalitas. Dari hasil pengujian uji asumsi klasik diperoleh hasil sebagai berikut:

\section{Uji Multikolinieritas}

Tabel 4 Hasil Uji Multikolinieritas

Sumber: Data IMF dan Worldometer diolah EViews 10

Variance Inflation Factors

Date: 08/31/20 Time: 17:06

Sample: 1236

Included observations: 153

\begin{tabular}{llll}
\hline \hline Variable & $\begin{array}{l}\text { Coefficient } \\
\text { Variance }\end{array}$ & $\begin{array}{l}\text { Uncentered } \\
\text { VIF }\end{array}$ & $\begin{array}{l}\text { Centered } \\
\text { VIF }\end{array}$ \\
\hline \hline TCASES & $9.27 \mathrm{E}-17$ & 10.20599 & 9.234988 \\
T_MORBID & $1.33 \mathrm{E}-08$ & 74.10436 & 1.954559 \\
D_START & $4.59 \mathrm{E}-08$ & 18.36210 & 2.690853 \\
CRITICAL & $7.45 \mathrm{E}-12$ & 9.242929 & 8.392758 \\
EXP01 & 0.000765 & 21.08367 & 2.380220 \\
DEBT & $5.11 \mathrm{E}-05$ & 5.269468 & 1.302006 \\
EMERGE & $6.68 \mathrm{E}-05$ & 5.248384 & 3.018678 \\
ADVANCE & 0.000118 & 8.133575 & 5.103420 \\
AFRIKA & 0.000386 & 12.59659 & 10.37366 \\
AMERICA & 0.000304 & 28.63787 & 14.03817 \\
ASIA & 0.000331 & 18.02357 & 12.72252 \\
EUROPE & 0.000903 & 1.091012 & 1.083881 \\
POP & $3.02 \mathrm{E}-22$ & 3.208112 & 2.854372 \\
TEST & $1.10 \mathrm{E}-19$ & 4.016821 & 3.621495 \\
C & 0.001280 & 236.7752 & NA \\
\hline \hline
\end{tabular}

Dari uji diagnostic koefisien varian inflation factor (VIF) diperoleh informasi bahwa hampir semua variabel memili VIF kecil, kecuali untuk variabel dummy ada yang memiliki VIF antara 10-14. Fakta ini tidak menjadi masalah karena nilai VIF besar dalam regresi dengan dummy varabel lumrah terjadi (Nachrowi \& Usman. 2010; Winarno, 2009). Artinya model regresi ini sudah memenuhi syarat terbebas dari masalah multikolineritas. 


\section{Al-Kharaj: Jurnal Ekonomi, Kenangan \& Bisnis Syariah}

Volume 3 No 1 (2021) 37-56 P-ISSN 2656-2871 E-ISSN 2656-4351

DOI: $10.47467 /$ alkharaj.v3i1.187

\section{Uji Hereoskedalitas}

Tabel 5 Hasil Uji Hereoskedalitas

Sumber: Data IMF dan Worldometer diolah EViews 10

Heteroskedasticity Test: Breusch-Pagan-Godfrey

\begin{tabular}{llll}
\hline \hline F-statistic & 1.215686 & Prob. F(14,138) & 0.2706 \\
Obs*R-squared & 16.79787 & Prob. Chi-Square(14) & 0.2671 \\
Scaled explained SS & 44.01308 & Prob. Chi-Square(14) & 0.0001 \\
\hline \hline
\end{tabular}

Tampak nilai probbailitas Chi-Square Obs*R-squared dan F Statistik bernilai 0.2671 atau lebih dari 0.05 . Artinya model memenuhi syarat homoskedalitas atau tidak ada gangguan heteroskedalitas.

\section{Uji Linieritas}

Uji linieritas dilakukan dengan menggunakan alat uji Ramsey RESET Test yang ada pada aplikasi Eviews 10. Hasilnya ditunjukkan pada Tabel 6. Tampak nilai probalilitas F statistic dalam uji Ramsey RESET Test senilai 0.0623 atau lebijh besar dari standar 0.05. Maknanya, model regresi ini memenuhi syarat linieritas.

Tabel 6 Hasil Uji Linieritas

Sumber: Data IMF dan Worldometer diolah EViews 10

Ramsey RESET Test

Equation: UNTITLED

Specification: G_GDP TCASES T_MORBID D_START CRITICAL EXP01 DEBT EMERGE ADVANCE AFRIKA AMERICA ASIA EUROPE POP TEST C

Omitted Variables: Squares of fitted values

\begin{tabular}{lccc}
\hline \hline & Value & Df & Probability \\
\cline { 2 - 4 } t-statistic & 1.879808 & 137 & 0.0623 \\
F-statistic & 3.533680 & $(1,137)$ & 0.0623 \\
Likelihood ratio & 3.896336 & 1 & 0.0484 \\
\hline \hline
\end{tabular}

F-test summary:

\begin{tabular}{lccc} 
& & \multicolumn{2}{c}{ Mean } \\
Test SSR & Sum of Sq. & Df & Squares \\
\cline { 2 - 4 } Restricted SSR & 0.002871 & 1 & 0.002871 \\
Unrestricted SSR & 0.114170 & 138 & 0.000827 \\
\hline
\end{tabular}

LR test summary:

\begin{tabular}{ll} 
& Value \\
\cline { 2 - 2 } Restricted LogL & 333.7412 \\
Unrestricted LogL & 335.6893 \\
\hline
\end{tabular}

\section{Uji Autokorelasi}




\section{Al-Kharaj: Jurnal Ekonomi, Kenangan \& Bisnis Syariah}

Volume 3 No 1 (2021) 37-56 P-ISSN 2656-2871 E-ISSN 2656-4351

DOI: $10.47467 /$ alkharaj.v3i1.187

Autokorelasi melruakan masalah yang sering terjadi dalam analisis statistikmenggunakan data times series. Uji ini dapat dilakukan dengan du acara: pertama membandingkan nilai Durbin Watson dengan nilai standar DW Tabel. Dari nilai DW hitung (Tabel 3) 2,027 tampak lebih besar dari nilai dU $(1,723)$ dan lebih kecil dari 4-dL (2.485). Atau dengan kata lain ada di wilayah bebas autokorelasi.. Untuk memastikannya perlu dikonfirmasi dengan uji Breusch-Godfrey Serial Correlation LM Test. Hasil ujinya disajikan dalam Tabel 7 berikut:

Tabel 7 Hasil Uji Autokorelasi

Sumber: Data IMF dan Worldometer diolah EViews 10

Breusch-Godfrey Serial Correlation LM Test:

\begin{tabular}{llll}
\hline \hline F-statistic & 0.829314 & Prob. F(2,131) & 0.4386 \\
Obs*R-squared & 1.837938 & Prob. Chi-Square(2) & 0.3989 \\
\hline \hline
\end{tabular}

Nilai probabilitas Chi-Square maupun probabilitas F-statistik 0.4386 dan 0.3989 . Keduanya sudah lebih besar dari 0.05 . Artinya, model regresi yang diteliti sudah terbebas dari masalah autokorelasi. Dengan demikian model regresi terakhir lebih valid dibanding model pertama.

\section{Uji Normalitas}

Uji normalitas dilakukan dengan melihat karakter kurva distribusi normal data penelitian. Dari grafis tampak mirip dengan kurva distribusi normal. Dari Tabel 8 diketahui nilai Jarque Bera sangat besar (157.196) dan nilai probabilitas (0.00) jauh di bawah 0.05 , menunjukkan bahwa data model regresi ternyata tidak atau belum memenuhi syarat normalitas. Adanya pandemic Covid-19 boleh jadi membuat data pengamatan tersebar tidak normal. Fakta kasus pandemi di banyak negara memang belum mereda, bahkan puncaknya belum dilewati. Jika waktu pengamatan diperpanjang, katakanlah, hingga akhir tahun, bisa jadi data sudah memenuhi syarat normal.

Tabel 8 Hasil Uji Normalitas

Sumber: Data IMF dan Worldometer diolah EViews 10

Dependent Variable:

RESID

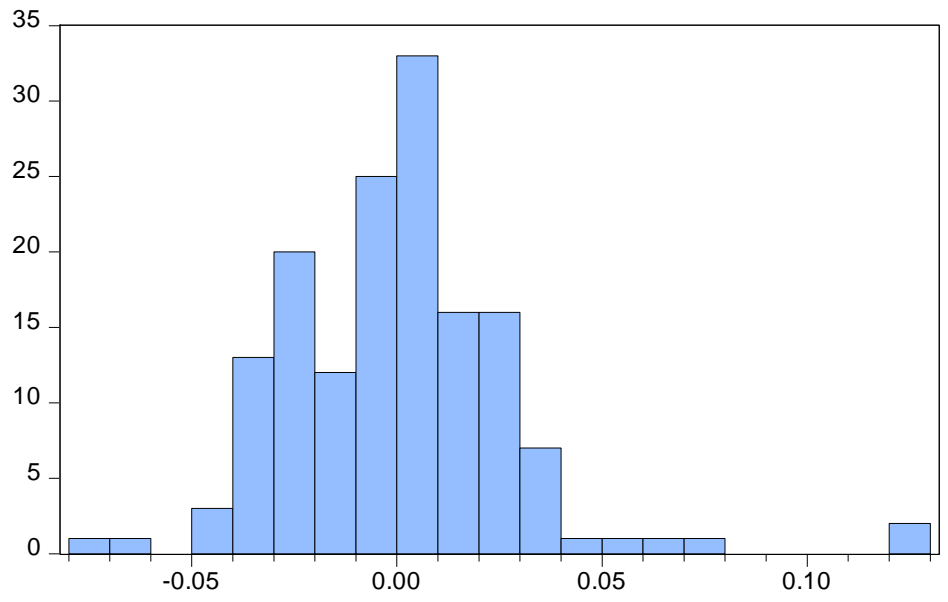

Series: Residuals

Sample 1217

Observations 153

Mean $\quad-4.92 \mathrm{e}-18$

Median $\quad 0.000366$

Maximum $\quad 0.125493$

Minimum $\quad-0.072717$

Std. Dev. $\quad 0.027407$

Skewness $\quad 1.110442$

Kurtosis $\quad 7.441427$

Jarque-Bera $\quad 157.1986$

Probability $\quad 0.000000$ 


\section{Al-Kharaj: Inrual Ekonomi, Kenangan \& Bisnis Syariah}

Volume 3 No 1 (2021) 37-56 P-ISSN 2656-2871 E-ISSN 2656-4351

DOI: $10.47467 /$ alkharaj.v3i1.187

Meski begitu, dari lima uji asumsi klasik, empat di antaranya sudah loloh uji asumsi klasik. Model regresi dapat digunakan untuk analisis ekonometrka karena setidaknya sudah terbebas dari masalah multikolinieritas, tidak ada heteroskedalitas, memenuhi syarat linieritas dan sudah bebas dar pengaruh autokorelasi.

\section{Pengaruh Pandemi Covid-19}

Dari analisis regresi ganda dengan dummy variabel (Tabel 3) diperoleh temuan bahwa dinamika pertumbuhan ekonomi negara terdampak dipengaruhi oleh jumlah kasus (DTCase), waktu terpapar (T_Morbid), G-GDP tahun sebelumnya, jumlah populasi (logpop), porsi belanja (Exp01), serta perbedaan kawasan (Asia, Amerika dan Afrika) dan perbedaan status negara (Advance). Sementara itu, rasio utang, kawasan Eropa dan negara berkembang tidak nyata berdampak bagi dinamika pertumbuhan ekonomi, negara-negara terdampak

Yang menarik, hampir semua variabel bebas berkorelasi negatif terhadap pertumbuhan ekonomi. Hanya dua yang berkorelasi positif, yaitu varabel jumlah kasus dan variabel porsi utang. Artinya, pada sitausi sekarang (di mana umumnya terjadi kontraksi) adanya tambahan kasus dan tambahan porsi utang bisa berdampak kepada peningkatan nilai negatif dari pertumbuhan ekonomi.

Sebaliknya, variabel lain --sepertii waktu terpapar, jumlah populasi, belanja pemerintas-- berdampak sebaliknya. Jika nilainya naik atau bertambah, makan memberi efek tekanan negatif bagi dinamika pertumbuhan ekonomi.

Soal dampak pandemi terhadap perekonomian telah disampaikan sejumlah peneliti lain sebelumnya. Pandemi Covid-19 berdampak bagi perekonomian Indonesia (Nasution et al (2020) serta Hadiwardojo dan Bhaskara (2020)), pasar modal Indonesia (Junaedi dan Faisal, 2020), perekonomian regiona NTB (Maryanti dan Netrawati, 2020), pasar keuangan global (Zhang et al, 2020), ekonomi global (Smith et al, 2009)dan makroekonomi global (2006).

\subsection{Dampak Perbedaan Kawasan dan Status Negara}

Untuk menjawab pertanyaan apakah perbedaan kawasan dan status negara berpengaruh dalam tatakelola mengatasi masalah pertumbuhan akibat pandemic COVID-19, digunakan data hasil regresi ganda dummy variable yang telah memenuhi syarat analisis statistic yang valid. Yakni menggunakan model regresi yang sudah terbebas dari uji asumsi klasik atau terbebas dari masalah multikolinieritas, heteroskedalitas, autokorelasi, lineritas dan normalitas. Data yang memenuhi syarat seperti tertera dalam Tabel 9.

Dari Tabel 9 diketahui bahwa perbedaan kawasan tampak ikut mempengaruhi dinamika pertumbuhan ekonomi negara-negara terdampak. Perbedaan kawasan terutama di Amerika, Asia dan Afrika tampak berbeda dengan kondisi di negara-negara Oceania. Sementara di Eropa kondisinya tidak berbeda nyata dengan di Australia dan sekitarnya.

Tabel 9 Hasil Regresi Ganda dengan Dummy Variable Sumber: Data IMF dan Worldometer diolah EViews 10 Dependent Variable: DG_GDP Method: Least Squares

Date: 08/31/20 Time: 17:21

Sample (adjusted): 3217 


\section{Al-Kharaj: Inrual Ekonomi, Kenangan \& Bisnis Syariah}

Volume 3 No 1 (2021) 37-56 P-ISSN 2656-2871 E-ISSN 2656-4351

DOI: $10.47467 /$ alkharaj.v3i1.187

Included observations: 147 after adjustments

\begin{tabular}{crrrr}
\hline \hline Variable & Coefficient & Std. Error & t-Statistic & Prob. \\
\hline \hline DTCASES & $4.15 \mathrm{E}-06$ & $1.84 \mathrm{E}-06$ & 2.252963 & 0.0259 \\
DTEST & $-1.22 \mathrm{E}-07$ & $8.79 \mathrm{E}-08$ & -1.386973 & 0.1678 \\
T_MORBID & -0.303046 & 0.037515 & -8.078086 & 0.0000 \\
G-GDP-1 & 0.000349 & 0.000490 & -0.711992 & 0.0477 \\
LOGPOP & -3.261571 & 0.868373 & -3.755957 & 0.0003 \\
AFRIKA & -12.92822 & 7.738935 & -1.670542 & 0.0972 \\
AMERICA & -14.40056 & 6.821408 & -2.111083 & 0.0366 \\
ASIA & -15.65950 & 7.085263 & -2.210150 & 0.0288 \\
EUROPE & -10.58930 & 11.87675 & -0.891599 & 0.3742 \\
EMERGE & -4.605343 & 3.326520 & -1.384433 & 0.1685 \\
ADVANCE & -15.53806 & 4.212644 & -3.688434 & 0.0003 \\
EXP01 & -0.279737 & 11.11455 & -2.516825 & 0.0130 \\
DEBT & 3.470767 & 2.986292 & 1.162233 & 0.2472 \\
C & 0.1801173 & 16.85937 & 10.68351 & 0.0000 \\
\hline \hline R-squared & 0.637264 & \multicolumn{2}{l}{ Mean dependent var } & 42.44898 \\
Adjusted R-squared & 0.601809 & S.D. dependent var & 17.97075 \\
S.E. of regression & 11.33997 & Akaike info criterion & 7.784937 \\
Sum squared resid & 17103.13 & Schwarz criterion & 8.069741 \\
Log likelihood & -558.1929 & Hannan-Quinn criter. & 7.900656 \\
F-statistic & 17.97369 & Durbin-Watson stat & 2.027738 \\
Prob(F-statistic) & 0.000000 & & \\
\hline \hline
\end{tabular}

Dari hasil analisis regresi berganda dengan dummy variabel sepintas diperoleh informasi bahwa variabel-variabel bebas secara simultan tampak mepengaruhi perkembangan pertumbuhan GDP dengan tingkat determinasi 63.73\% (ditunjukkan R-squared 0.6373). Artinya model regresi dapat menjelaskan sebanyak $63.73 \%$, sisanya sebesar $26,27 \%$ dipengrauhi oleh variabel lain yang tidak diteliti. Secara parsial, pada level kepercayaan 90\% (standar error 10\%), jumlah kasus, waktu paparan, kemampuan bekanja, serta perbedaan kawasan (Amerika, Asia, Afrika) dan status negara (Advance) mempengaruhi secara signifikans dinamika pertumbuhan GDP. Sementara jumlah tes dan utang negara tidak nyata berpengaruh terhadap dinamika pertumbuhan ekonomi.

Koefisien relasi untuk variabel dummy Asia tampak lebih besar di Asia dibanding Amerika dan Afrika. Ini memberi makna pengarus kawasan di Asia relatif lebih sensitif di banding dampak kawasan di Amerika dan Afrika, apalagi dengan negara-negara Australia/Oceania. Sementara kawasan Eropa tidak berbeda dengan pengaruh kawasan di Australia/Oceania.

Variabel dummy Advance tampak berpengaruh signifikans terhadap dinamika pertumbuhan GDP. Sementara variabel dummy Emerge tampak tidak berpengaruh nyata terhadap dinamika pertumbuhan ekonomi. Ini memberi indikasi bahwa tatakelola dampak pandemi di negara maju terbukti lebih baik dibanding negara miskin. Sementara tatakelola dampak pandemi negara berkembang dan menengah ternyata tidak jauh berbeda dengan kemampuan negara-negara berpenghasilan rendah. Dengan demikina, perlu upaya lebih untuk meningkatkan efsiensi dan 


\section{Al-Kharaj: Inrual Ekonomi, Kenangan \& Bisnis Syariah}

Volume 3 No 1 (2021) 37-56 P-ISSN 2656-2871 E-ISSN 2656-4351

DOI: $10.47467 /$ alkharaj.v3i1.187

efektivitas penaanganan dampak pandemi coronavirus. Akhirnya dari penelitian ditemukan fakta bahwa uji hipotesis terhadap model ekonometri:

G-GDP $=\beta_{0}+\beta_{1}$ TCases $+\beta_{2}$ TDeath $+\beta_{3}$ T-Critic $+\beta_{4}$ Pop $+\beta_{5}$ T-Morbids $+\beta_{6}$ G-GDP$1+\beta_{7}$ Expen $+\beta_{8}$ Debt $+\beta_{9}$ Afrika $+\beta_{10}$ Asia $+\beta_{11}$ Eropa $+\beta_{12}$ Amerika $+\beta_{13}$ Emerge + $\beta_{14}$ Advance $+\varepsilon$

Menghasilkan model ekonometri yang valid pada level kepercayaan $90 \%$ atau $\alpha 10 \%$ dan koefisen determinasi 63,73\% ( $\left.\mathrm{R}^{2} 0.6373\right)$ sebagai berikut:

G-GDP $=0.180117+0.00000415$ DTCASES $-0.303046 \mathrm{~T}$ MORBID $+0.000349 \mathrm{G}-\mathrm{GDP}-$ 3.261571LOGPOP - 12.92822AFRIKA - 14.40056AMERICA - 15.65950ASIA 15.53806Advance - 0.279737EXP01

Dari model ekonometri yang sudah valid dan sahih ini, diperoleh intrepretasi sebagai berikut:

- Variabel kasus pandemic, waktu paparan, jumlah penduduk, perbedaan kawasan dan perbedaan status negara dapat menjelaskan dinamika pertumbuhan ekonomi negarta terdampak sebesar 63,73\%, sisanya dipengaruhi oleh variabel lain yang tidak diteliti.

- Jika pandemic terkendali (dalam kasus dan waktu paparan) serta tidak ada disparitas tatakelola antara kawasan dan antar status negara, maka pertumbuhan ekonomi global berpotensi positif $0.18 \%$

- Jika jumlah kasus meningkat 1 juta, maka pertumbuhan ekonomi akan cenderung tertekan seebsar sebesar 0,415\%.

- Jika waktu terpapar COVID-19 meningkat satu satuan, maka pertumbuhan ekonomi tidak ada pandemic dan jumlah tidak ada pengaruh kawasan

- Jika pertumbuhan ekonomi sebelumnya tumbuh 1\%, maka pertumbuhan ekonomi tahun berikutnya akan tumbuh sebesar $0,000349 \%$.

- Jika jumlah penduduk naik 1 juta, maka pertumbuhan ekonomi akan cenderung tergerus sebesar bilangan logaritma 0.00326 atau setara 1,007 poin.

- Jika kasus pandemic berlangsung di kawasan Afrika, maka dampak terhadap pertumbuhan ekonomi di kawasan ini cenderung lebih buruk sekitar 112,93 kali dari dampak pandemic di kawasan Australia/Oceania.

- Jika kasus pandem terjadi di kawasan Amerika, dampak terhadap pertumbuhan ekonomi di kawasan ini cenderung lebij buruk 14,4 kali dari dampak pandemi di kawasan Australia/Oceania.

- Jika kasus pandem terjadi di kawasan Asia, dampak terhadap pertumbuhan ekonomi di kawasan ini cenderung lebij buruk 15,66 kali dari dampak pandemi di kawasan Australia/Oceania.

- Dampak pandemi terhadap pertumbuhan ekonomi negara di kawasan Eropa tidak berbeda nyata dengan dampak pandemic di kawasan Australia/Oceania.

- Secara relatif, dampak pandemi terhadap pertumbuahn ekonomi di kawasan Asia lebih berat dibanding kawasan lainnya. Urutan dampak pendemi terhadap pertumbuhan ekonomi kawasan berturut-turut dari yang terbeerat ke yang teringan adalah: Asia, Amerika, Afrika, Eropa dan Australia/Oceania. 


\section{Al-Kharaj: Jurnal Ekonomi, Kenangan \& Bisnis Syariah}

Volume 3 No 1 (2021) 37-56 P-ISSN 2656-2871 E-ISSN 2656-4351

DOI: $10.47467 /$ alkharaj.v3i1.187

- Jika pandemic menimpa negara-negata dengan status negara maju (Advance), maka dampaknya cenderung lebih buruk 15.53 kali dari dampak pandemi yang dialami negara miskin.

- Dampak pandemi yang menimpa negara-negaa menengah tidak berbeda alias hampir sama dengan dampak yang diterima oleh negara-negara miskin. Artinya, tatakelola negara menngah harus dikoreksi agar lebih baik dan efektif hasilnya.

- Jika belanja pemerintah untuk mengatasi pandemi dinaikan sebesar satu juta dolar saat ini (periode Januari - Agustus 2020), maka Langkah ini berpotensi mengurangi dampak kontraksi sebesar $0,27 \%$

\section{KESIMPULAN}

Pandemi COVID-19 telah menimbaulkan dampak multi sektor. Pandemi ini telah ikut memperparah efek kontraksi perekonomian bagi negara-negara di kawasan Asia, Amerika, Afrika, Eropa dan Australia/Oceania. Variabel kasus pandemi, waktu paparan, jumlah penduduk, perbedaan kawasan dan perbedaan status negara berpengaruh terhadap pertumbuhan ekonomi negara terdampak dengan koefisien korelasi 0.6373.

Jika pandemi terkendali (dalam kasus dan waktu paparan) serta tidak ada disparitas tatakelola antara kawasan dan antar status negara, maka pertumbuhan ekonomi global berpotensi positif $0.18 \%$. Jika belanja pemerintah untuk mengatasi pandemi dinaikkan sebesar satu juta dolar, maka langkah ini berpotensi mengurangi dampak kontraksi sebesar $0,27 \%$

Tatakelola dampak pandemi di kawasan Asia, Amerika dan Afrika berbeda signifikans dengan tatakelola di negara kawasan Australia/Oceania. Sementara tatakelola pandemi di Eropa tidak berbeda signifikans dengan tatakelola negara Australia/Oceania. Perbedaan status negara maju berbeda nyata dengan negara miskin. Tetapi, status negara menengah dengan negara miskin tidak berbeda nyata dengan tatakelola penanganan pandemi Covid-19. Secara relatif, dampak pandemi terhadap pertumbuhan ekonomi di kawasan Asia, Amerika dan Afrika lebih berat dibanding kawasan lainnya. Urutan dampak pendemi terhadap pertumbuhan ekonomi kawasan dari yang terberat ke yang teringan adalah: Asia, Amerika, Afrika, Eropa dan Australia/Oceania.

\section{IMPLIKASI DAN KETERBATASAN}

Hasil penelitian memberi implikasi bahwa semua negara di dunai perlu terus mewasdai pertambahan kasus dan waktu paparan pandemic COVID-19 agar tidak berdampak lebih tajam bagi kontraksi pertumbuhan ekonomi. Pada saat yang bersamaan, negara-negara terdampak pandemi perlu lebih berhati-hati mengelola fiscal moneter, khususnya bekanja poemerintah dan tata kelola utang. Efektifitas belanja dan utang perlu terus ditingkatkan agar berdampak positif bagi pemulihan ekonomi.

Kewaspadaan lebih diperlukan bagi negara do kawasan Asia, Amerika dan Afrika. Dampak pandemic di kwasan ini lebih sensitif dibanding di negara kawasan Australia/Oceania atau kawaan Eropa. Negara menengah perlu lebih pruden dalam 


\section{Al-Kharaj: Jurnal Ekonomi, Kenangan \& Bisnis Syariah}

Volume 3 No 1 (2021) 37-56 P-ISSN 2656-2871 E-ISSN 2656-4351

DOI: $10.47467 /$ alkharaj.v3i1.187

mengelola pandemic agar memiliki efektivitas yang lebih baik dari negara berpenghasilan rendah.

Penelitian ini memiliki keterbatsan waktu dan data yang tidak semuanya lengkap. Perlu penelitian lanjutan dengan data yang lebih banyak dan lengkap, rentang waktu yang lebih lama, agar memperoleh kesimpulan penelitian yang lebih reliabel, valid dan sahih secara ilmiah.

\section{Penghargaan}

Peneliti menyamolaikan terima kasih kepada jajaran LPPM dan rektorat kampis IAI-N Laa Roiba Bogor yang telah ikut mendukung kalancaran penelitian ini. Terima kasih juga kami sampaikan kepada Panitia SNKN 2020 yang telah memberi kesempatan untuk menyampaikan makalah ini.

\section{DAFTAR PUSTAKA}

Bjork, Gordon J. (1999). The Way It Worked and Why It Won't: Structural Change and the Slowdown of U.S. Economic Growth. Westport, CT; London: Praeger. pp. 2, 67. ISBN 978-0-275-96532-7.

Gordon, Robert J. (2016). The Rise and Fall of American Growth. Princeton, NJ USA: Princeton University Press. pp. 38-39. ISBN 978-0-691-14772-7.

Hasnia, Hasnia; \& Julianti, Sita. Impact of COVID-19 on Interest Rates. Journal of Asian Multicultural Research for Economy and Management Study 1(1). Pp 007-011.

Dirjen Pencegahan dan Pengendalian Penyakit (P2P) Kemenkes RI. Pedoman Pencegahan dan Pengendalian COVID-19. Jakarta: Dirjen P2P Kementerian Kesehatan RI.

Gugus Tugas COVID-19. 2020. Tentang Novel Coronavirus (NCov). Jakarta: Gugas COVID-19.

Georgieva, Kristalina. 2020. Fiscal Monitoring: Policies to Support Peoplr Durig the COVID-19 Pandemic. Washington DC: IMF. ISBN 978-1-51353-769-6.

Hadiwardoyo, W.; \& Baskara. 2020. Kerugian Ekonomi Nasional Akibat Pandemi Covid-19. Journal of Business \& ..., 2020 - jurnal.umj.ac.id

Hasnia, Hasnia;\& Julianti, Sita. Impact of Covid-19 on Interest Rates. Journal of Asian Multicultural Research for Economy and Management Study: 1(1), pp

Junaedi, Dedi. 2020. Dampak Pandemi Covid-19 terhadap Pasar Modal di Indonesia: Studi Kasus Indeks Saham Komposit (IHSG). Al-Kharaj: Jurnal Ekonomi, Keuangan \& Bisnis Syariah 2 (4) 2020.

Junaedi, D., \& Salistia, F. 2020. Dampak Pendemi Covid-19 terhadap Pertumbuhan Ekonomi Negara-negara Terdampak. Paper Prosiding Simponium Nasional Keuangan Negara (SNKN) 2020. Jakarta: BPPK Kementerian Keuangan RI. 


\section{Al-Kharaj: Inrual Ekonomi, Kenangan \& Bisnis Syariah}

Volume 3 No 1 (2021) 37-56 P-ISSN 2656-2871 E-ISSN 2656-4351

DOI: $10.47467 /$ alkharaj.v3i1.187

Majumder, Maimuna and Mandl, Kenneth D. 2020. Early Transmissibility Assessment of a Novel Coronavirus in Wuhan, China. Harvard University - Computational Health Informatics Program - Posted: 24 Jan 2020 Last revised: 27 Jan 2020.

Mankiw, N. Gregory. 2004. Principles of Economics. 3rd Ed. Harvard: Thomson SouthWestern.

Maryanti, S.; IGAO Netrawati, I.G...A.O. 2020. Pandemi Covid-19 dan Implikasinya Pada Perekonomian NTB. ejurnal.binawakya.or.id

Maziarz, Mariusz. 2017. The Reinhart-Rogoff controversy as an instance of the 'emerging contrary result' phenomenon. Journal of Economic Methodology. Volume 24, Issue 2. December 2017, pp1-13. doi:10.1080/1350178X.2017.1302598. ISSN 1350-178X

McEachern, W.A. 2008. Economics Principles: A Contemporary Introduction. Virginia: South-Western Cengage Learning. ISBN 978-0538453066.

McKibbin, WJ; \& Sidorenko, A. 2006. Global macroeconomic consequences of pandemic influenza. Cambera: ANU, cama.crawford.anu.edu.au

Mulyani, Sri. 2020. Ekonomi Indonesia Masuk Skenario Sangat Berat. Diakses dari Detik.com pada Kamis 7 Mei 2020 pukul 8.30.

Mulyani, Sri. 2020. Pemerintah Waspada Dampak Pandemi COVID-19 Terhadap Ekonomi Indonesia. Siaran pers Kenenterian Keuangan RI pada 17 SAril 2020. diaksi dari portal https://www.kemenkeu.go.id/publikasi/siaran-pers/siaranpers-pemerintah-waspada-dampak-pandemi-COVID-19-terhadap-ekonomiindonesia/ pada 7 Mei 2020 pukul 11.00 WIB.

Nachrowi, D.N.; \& Usman, H. 2006. Ekonometeri untuk Analisis Ekonomi dan Keuangan. Jakarta: Lembaga Penerbit FEUI

Nasution, DAD; Erlina, E.; \& I Muda, I. 2020. Penelitian ini Dampak Pandemi COVID19 terhadap Perekonomian Indonesia. Jurnal Benefita: Ekonomi. ejournal.lldikti10.id

Neufeld, Dorothy..2020. COVID-19 Downturn BEACH Stocks: \$332B in Value Novel coronavirus 2019-nCoV: early estimation of epidemiological parameters and epidemic prediction - Jonathan M. Read et al, Jan. 23,2020.

Sikki, K.L. 2020. Kebijakan Ekonomi Arab Saudi dalam Mengantisipasi Pandemi Covid-19. Journal of Islamic Civilization. journal2.unusa.ac.id.

Smith, R.D.; Keogh-Brown, M.R.; Barnett, T.; Tait, J. 2009. The economy-wide impact of pandemic influenza on the UK: a computable general equilibrium modelling experiment. bmj.com. 


\section{Al-Kharaj: Jurnal Ėkonomi, Kenanczan \& Bisnis Syarial}

Volume 3 No 1 (2021) 37-56 P-ISSN 2656-2871 E-ISSN 2656-4351

DOI: $10.47467 /$ alkharaj.v3i1.187

Zhang,D.; Hu, M; \& Ji, Q.2020. Financial markets under the global pandemic of COVID19. Finance Research Letters, 2020 - Elsevier

Winarno, W.W. 2009. Analisis Ekonomi dan Statistika dengan Eviews. $2^{\text {nd }}$ Ed. Yogyakarta: UPP STIM YKPN. 